DOI https://doi.org/10.18551/rjoas.2017-12.10

\title{
RURAL TOURISM AS ONE OF THE ELEMENTS OF VILLAGES' SOCIO-ECONOMIC DEVELOPMENT
}

\author{
Polukhina M.G. ${ }^{*}$, Panarina V.I., Zhilina L.N., Researchers \\ Orel State Agrarian University, Orel City, Russia \\ Shevaldova T.V., Researcher \\ Ulyanovsk State Agrarian University, Ulyanovsk, Russia \\ *E-mail: redhvost@yandex.ru
}

\begin{abstract}
At present, special attention is paid to the diversification of the rural economy, to the development of non-agricultural activities, employment expansion and incomes increase of the rural population on this basis. Existence of the large number of unemployed rural populations and the non-availability of possibilities to create more jobs cause combination of negative social and economic affects. One of the alternative employment ways is rural tourism. The developed rural tourism positively affects: the creation of new jobs, involvement and consolidation of youth in rural areas, growth of employment and reducing migration, increasing tax revenues to the local and regional budgets, social development of rural areas, rational use of natural resources, preservation of cultural heritage and folk crafts. The results of the study showed that there is decrease of rural population number, and the reduction of villages in Russia. However, in some regions of the Central Federal District, local authorities pay special attention to the development of rural tourism. Although there are still many unsolved problems for the development of this kind of activity. The conducted SWOTanalysis allowed determining the main directions of tourism development in rural areas of the Russian Federation.
\end{abstract}

\section{KEY WORDS}

Economy, tourism, rural areas, state support, grant support, programs of tourism Economy, tourism, rural areas, state support, grant support.

The sustainable development of rural areas cannot be imagined without solution of the rural employment problem. Large number of unemployed population has an extremely negative impact on the social and economic development of the village. As a result, the development of domestic tourism, first of all rural tourism, as promising direction of alternative employment, takes central stage. Foreign and domestic experience of the number of Russian regions showed that the development of rural tourism can be beneficial for involving and consolidation of youth in rural areas, growth of employment and reducing migration, increasing tax revenues to the local and regional budgets, social development of rural areas, rational use of natural resources, preservation of cultural heritage and folk crafts.

The Russian Federation, like no other country in the world, has unique natural resources. Most of its territory is occupied by forest fund lands $-65.8 \%$ and agricultural land $-22.4 \%$. Therefore, the important task is to preserve and develop rural areas and regions with an agrarian bias. It should be noted that in recent years an unfavorable situation which slowed down the social and economic development happens in the village: low incomes of rural population, the lack of adequate labor conditions, the unfavorable demographic situation, the underdeveloped socio- engineering and transport infrastructure [1].

According to the annual monitoring, the number of rural settlements in the territory of the Russian Federation has decreased by $4.7 \%$ in recent years (Figure 1) [2]. The reasons for this reduction can be: the elimination of depopulated villages, or their integration in order to reduce management costs. 
In recent years, the rural population tends to decrease, so in 2017 it was 37772 thousand people, which is 3.7\% less than in 2000 (Figure 2). This situation has developed not only as the result of natural population decline, but also because of negative migration balance.

Low employment of the rural population does not contribute to the socio-economic development. In 2015, the occupational level of rural population varied in the regions of the Russian Federation from $48 \%$ to $70.5 \%$. Agriculture, trade personal services, and education are the main work of rural people. According to the sociological survey, the main problems affecting the rural population are: rising prices for goods and services; low level of wages, pensions, scholarships and benefits; problems of employment [2].

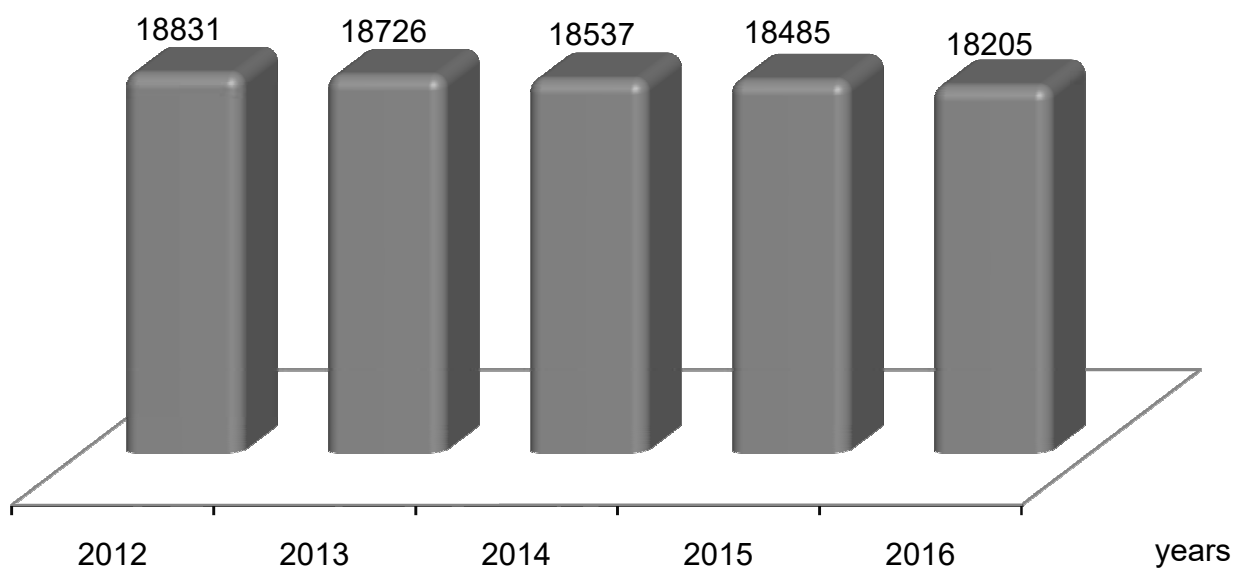

Figure 1 - The number of rural settlements of the Russian Federation

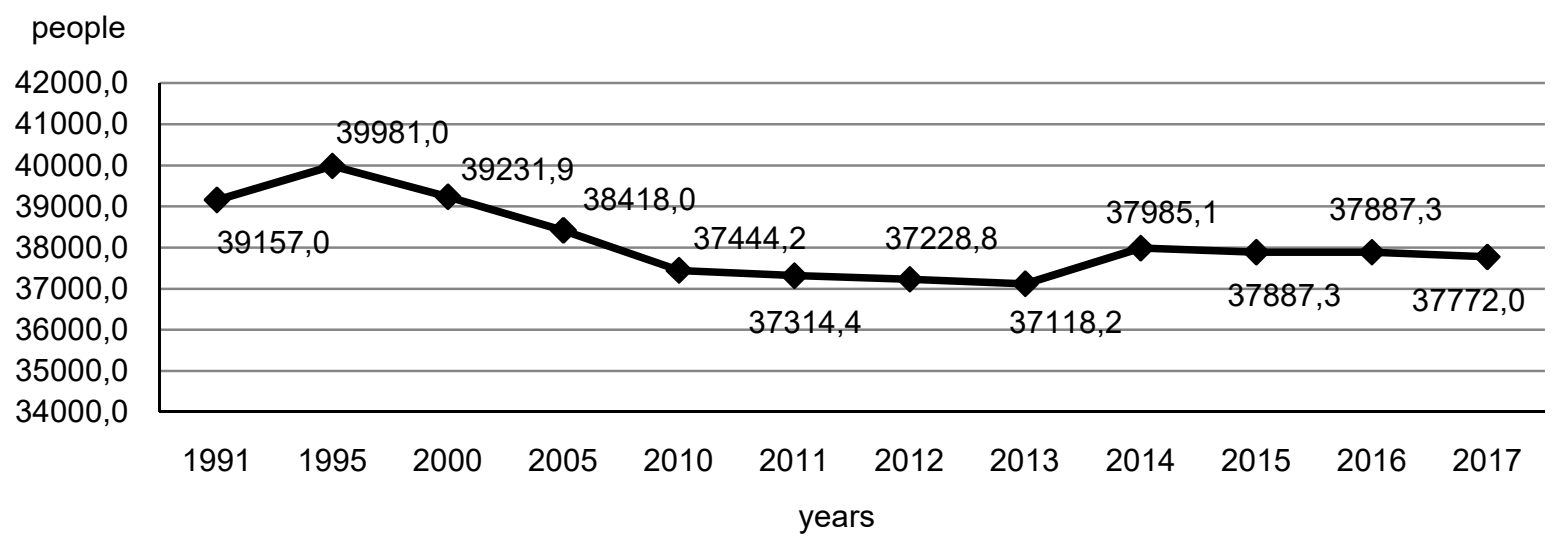

Figure 2 - Number of the rural population of the Russian Federation

Existence of the large number of unemployed rural population and low probability of creating new jobs entail combination of negative social and economic effects. Therefore, the diversification of the rural economy, the development of non-agricultural activities and services, which will become the basis for increasing employment and raising the incomes of the rural population, becomes topical. Tourism can be one of the alternative employments.

Tourism with its form verities (culture-related tourism, hunting and fishing tourism, rural tourism, agrarian tourism, eco-tourism, sports tourism) is optimal alternative for creating new jobs, reducing of migration, attracting young people to development of this sphere of activity, improving social and economic situation, development of engineering and road infrastructure, development and preservation of cultural heritage.

It should be noted that tourism became one of the first branches of the Russian economy which could successfully affect the import substitution of the provided services. 
Compared with the previous year, in 2016, according to the Association of Russian Tour Operators, the demand for domestic tourism grew by 15\% [3]. In 2016, according to the Ministry of Agriculture of Russia, 1236 organizations were engaged in the development of rural tourism [4].

The growth of domestic tourism is provided with the existence of an extensive tourist base, which increases every year, so the number of museums for the investigate period more than doubled, the number of cultural heritage objects increased by 3.4 times, the number of state nature reserves by $30 \%$, the number of national parks more than doubled (Figure1).

Table 1 - The tourist base of the Russian Federation

\begin{tabular}{|l|c|c|c|c|c|c|}
\hline \multicolumn{1}{|c|}{$\mathrm{n} / \mathrm{n}$} & 1991 & 1995 & 2000 & 2005 & 2010 & 2015 \\
\hline Number of museums & 1282 & 1725 & 2047 & 2285 & 2578 & 2758 \\
\hline Number of cultural heritage objects, thousands & 49,6 & 64,5 & 84,9 & 87,8 & 143,4 & 171,1 \\
\hline Number of state natural parks & 79 & 94 & 100 & 100 & 101 & 103 \\
\hline Number of state parks & 22 & 30 & 35 & 35 & 40 & 48 \\
\hline
\end{tabular}

In recent years state provides purposeful support of the domestic tourism development through the implementation of:

Strategies for sustainable development of rural areas of the Russian Federation for the period until 2030 [5];

Concept of sustainable development of rural areas of the Russian Federation for the period until 2020 [6];

The activities of federal target program "Development of domestic and incoming tourism in the Russian Federation (2011 - 2018)" are directed to develop tourist and recreational complex of the Russian Federation, as well as improve the quality of tourist services and promote the tourist product of the Russian Federation in the world and domestic travel services markets [7];

The state program of the Russian Federation "Development of Culture and Tourism" for 2013-2020, whose tasks are the improving of the quality and services availability in the sphere of domestic and international tourism, creating favorable conditions for sustainable development of the cultural and tourism sector [8];

Grant support of local initiatives of citizens lived in rural areas in the part of the federal target program "Sustainable development of rural areas for 2014-2017 and for the period until 2020" is carried out in such priority directions as the creation and arrangement of parks, shores, beaches and other public places; preservation and restoration of natural landscapes, historical and cultural monuments; support of national cultural traditions, folk crafts (creation of museums of peasant life, traditional crafts and skills, organization of sightseeing festivals of interethnic culture, support of informative projects about popularization of national cultural traditions) [9].

The development of tourism, including rural tourism, is carried out as a part of regional concepts, programs and subprograms at the regional and local level. Special economic zones of a tourist-recreational type of federal and regional significance are created.

However, in spite of the above listed, the problem of legislative regulation of tourism in the Russian Federation remains unresolved and there is no approved concept of "rural tourism" in any of the normative legal acts concerning tourism.

Currently, this line of activity is governed by more general legislative acts, such as: "On the basics of tourism in the Russian Federation" [10]; Civil Code of the Russian Federation, Chapter 39. In spite of the absence of specialized legislative acts that significantly thwart progress of rural tourism, according to Russian Federal Agency for Tourism, the Arkhangelsk, Kaluga, Tula, Kaliningrad regions, the Republic of Tatarstan, the Republic of Ingushetia, the Republic of Altai, the Krasnodar Krai, the Altai Krai, Irkutsk, Kostroma and Saratov regions actively engaged in its development. The annual potential demand for rural tourism in Russia is about 600 thousand people [7]. 
The development of tourism on the territory of individual regions depends on its suitability for this type of tourism activity and the available potential. Studies, conducted by various agencies and publications, which are summarized in ratings, permit to get general idea of the region's tourism potential [11, 12]. The National Rating of the Tourist Attractiveness of Russian Regions, conducted by the Central Executive Committee "Rating" and the magazine "Rest in Russia" is one of them (Figure 3). The main criteria of the rating were [13]: the level of tourism business development and infrastructure; the importance of the tourism industry in the region's economy; turnover of tourist services; popularity of the region among Russians; the popularity of the region among foreigners; tourist uniqueness; ecological "health" of the region; crime situation; interest to the region as place of rest in Internet; promotion of the region's tourism potential in the information space.

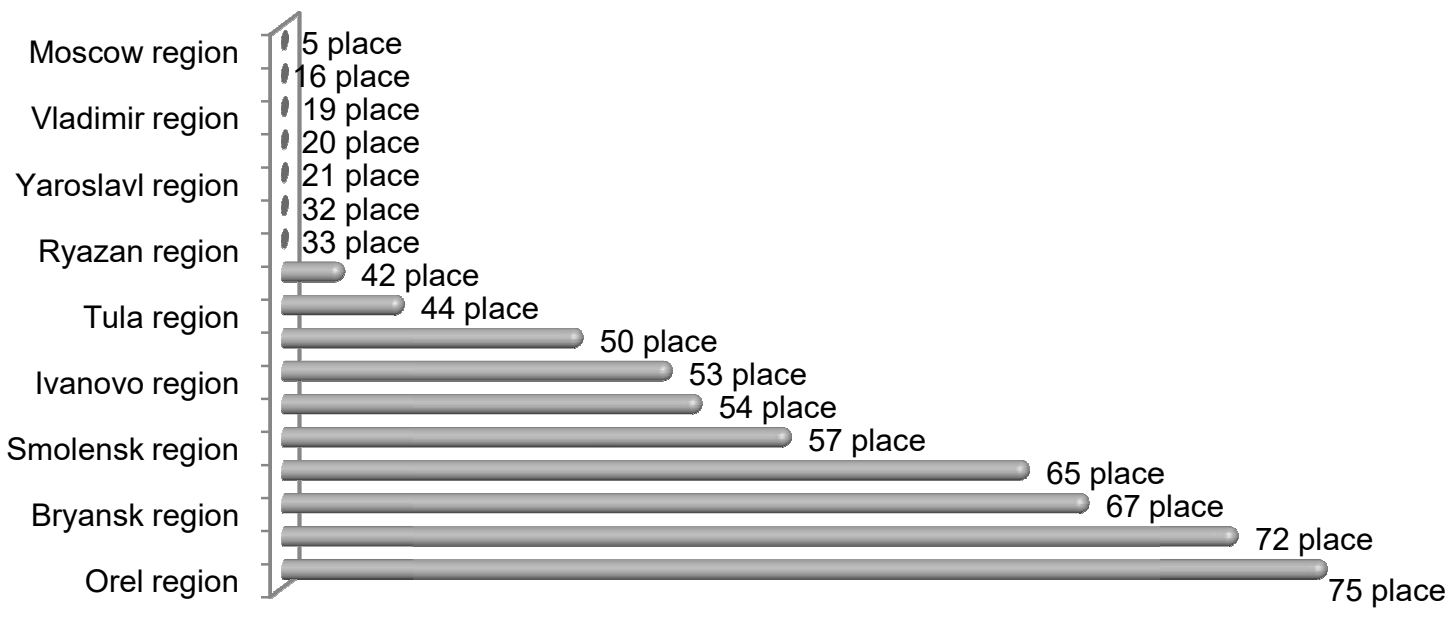

Figure 3 - Rating of the tourist attraction of the Central Federal District regions in 2016

According to the results of this rating, the leaders of tourist attraction in the regions of the Central Federal District were Moscow, Tver, Vladimir, Kaluga and Yaroslavl regions. Eight regions: Lipetsk, Ryazan, Voronezh, Tula, Belgorod, Ivanovo, Kostroma and Smolensk are in medium group. These regions have a good potential in the development of tourism, however, because of some reasons, for example, undeveloped infrastructure or weak popularization of tourism products cannot move to the leading group. Outsiders among the regions of the Central Federal District are the Kursk, Bryansk, Orel and Tambov regions, because all these regions are economically weak. However, many regions make enormous efforts to develop tourism and have high scores on certain rating criteria.

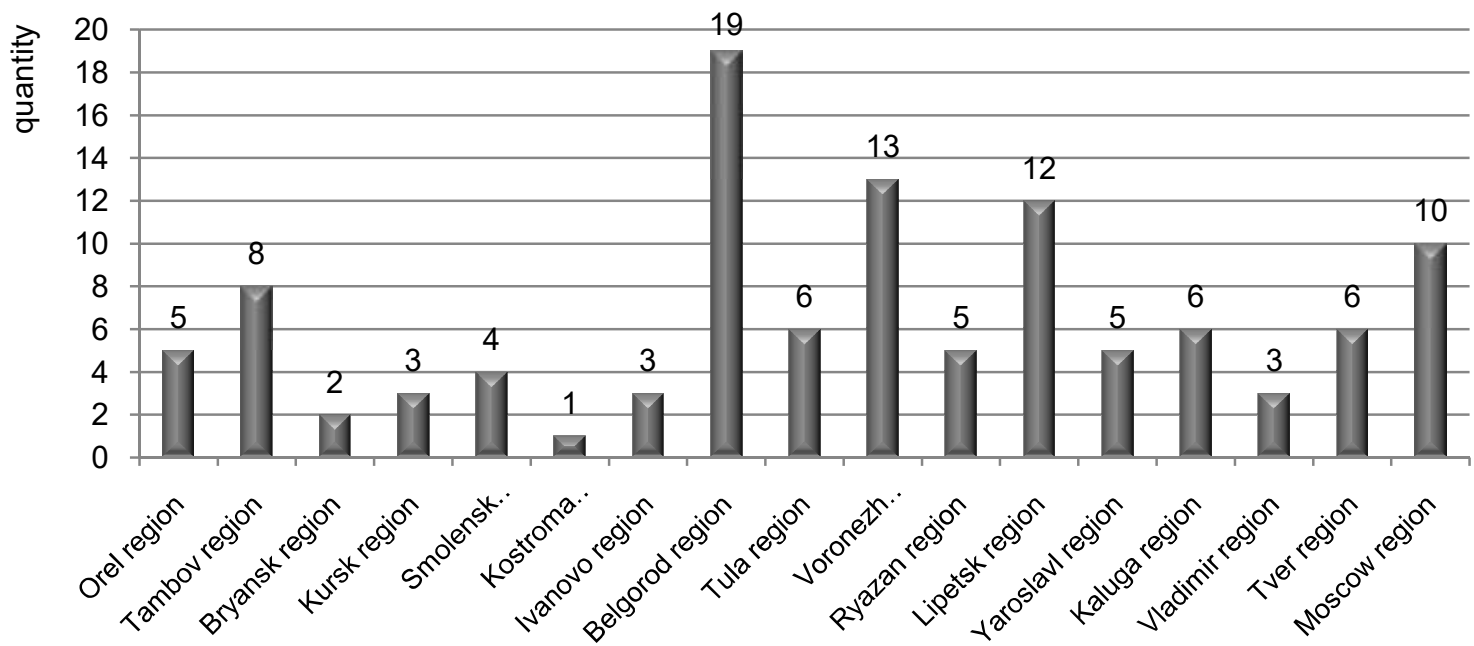

Figure 4 - Distribution of rural tourism destinations in the Central Federal District 
Table 2 - SWOT-analysis of tourism in rural areas of the Russian Federation

\begin{tabular}{|c|c|}
\hline Strength (S) & Weaknesses (W) \\
\hline $\begin{array}{l}\text { 1. In the Russian Federation as of } 01.01 .2016 \text { there are } 1,592 \\
\text { urban settlements and } 18,177 \text { rural. } \\
\text { 2. Wide variety of climatic conditions } \\
\text { 3. Rich natural and resources potential of rural areas of Russia } \\
\text { 4. A variety of cultural and historical heritage (ancient manors of } \\
\text { the nobility, churches, monasteries, sacred springs, military } \\
\text { monuments, archaeological sites). } \\
\text { 5. Wide range of events held in different regions of the Russian } \\
\text { Federation all year round } \\
\text { 6. The presence of sanatoriums, health camps for children, } \\
\text { recreation centers, boarding houses (children's recreation camps } \\
\text { - } 2.2 \text { thousand). The availability of secondary special and higher } \\
\text { educational institutions training cadres for the tourism industry. } \\
\text { 7. The Federal Center for Agricultural Counseling and Retraining } \\
\text { the Personnel of the Agro-industrial Complex, including those } \\
\text { engaged in retraining and consulting in the sphere of rural } \\
\text { tourism. } \\
\text { 8. Production of ecologically pure production in personal } \\
\text { subsidiary farms and collective farms. } \\
\text { 9. Federal State Program "Development of domestic and } \\
\text { incoming tourism in the Russian Federation for } 2011-2018 " . \\
\text { 10. The Strategy of Tourism Development in the Russian } \\
\text { Federation for the Period to } 2020 \text {. } \\
\text { 11. Federal State Program "Sustainable development of rural } \\
\text { areas for } 2014-2017 \text { and for the period until } 2020 " \\
\text { 12. Created structures for supporting small and medium-sized } \\
\text { enterprises in the regions. } \\
\text { 13. Developed transport network. } \\
\text { 14. The draft federal program "Development of domestic and } \\
\text { incoming tourism in the Russian Federation for the years } 2019- \\
\text { 2025" was developed and was agreed upon. }\end{array}$ & $\begin{array}{l}\text { 1. Insufficiently effective use of existing } \\
\text { advantages of economic and geographical } \\
\text { position of regions. } \\
\text { 2. Weak regional branding and regional } \\
\text { tourism products. } \\
\text { 3. Low awareness of the rural population of } \\
\text { the regions about such type of tourism as } \\
\text { rural. } \\
\text { 4. Weak awareness of the population about } \\
\text { the tourism potential of their region, lack of } \\
\text { special tourist information on the streets, } \\
\text { service facilities and display. } \\
\text { 5. Absence of the unified base of Russian } \\
\text { regions tourist resources. } \\
6 \text {. Absence of the unified rules of the service } \\
\text { provision in rural tourism. } \\
\text { 7. Regional travel agencies do not have } \\
\text { information about the objects of rural } \\
\text { tourism. } \\
8 \text {. The unsatisfactory state of most cultural } \\
\text { heritage objects. } \\
\text { 9. The lack of incentive measures to support } \\
\text { and develop small business in rural tourism. } \\
\text { 10. Low safety of travel to some natural } \\
\text { monuments. } \\
\text { 11. Insufficient demonstration of the goods of } \\
\text { national art crafts and their promotion. } \\
\text { 12. Lack of research on the analysis of } \\
\text { demand for services. } \\
\text { 13. The possibilities of weekend tours are } \\
\text { not sufficiently evaluated. }\end{array}$ \\
\hline Opportunities (O) & \\
\hline $\begin{array}{l}\text { 1. The interest of local governments in the development of rural } \\
\text { tourism. } \\
\text { 2. Development of rural infrastructure. } \\
\text { 3. Increasing the living standards of the rural population of the } \\
\text { region. } \\
\text { 4. Development of small and medium-sized enterprises in rural } \\
\text { areas. } \\
\text { 5. Active promotion of grant support for local initiatives under the } \\
\text { program of the Federal Target Program "Sustainable } \\
\text { Development of Rural Areas for } 2014-2017 \text { and for the Period to } \\
\text { 2020" } \\
\text { 6. Development of public-private partnership in the sphere of rural } \\
\text { tourism. } \\
\text { 7. Creation of brands in Russian regions. } \\
\text { 8. Improving the quality of advertising and information support for } \\
\text { the tourism sector. } \\
\text { 9. Formation of competitive regional tourist products. } \\
\text { 10. Increase of the cultural level of the country's population. } \\
\text { 11. Conservation of cultural and historical heritage. } \\
\text { 12. Development of small business in rural areas } \\
\text { 13. Diversification of the economy in rural areas } \\
\text { 14. Reduced out-migration of people from villages }\end{array}$ & $\begin{array}{l}\text { 1. Imperfection of the regulatory and } \\
\text { legislative framework in the field of rural } \\
\text { tourism. } \\
\text { 2. Low level of recreation culture. } \\
\text { 3. Decrease in the number of rural } \\
\text { population in the regions of the Russian } \\
\text { Federation. } \\
\text { 4. Decrease in the solvency of the population } \\
\text { of the country. } \\
\text { 5. Strong competition on the price / quality } \\
\text { ratio from foreign countries. } \\
6 \text {. Lack of state support of the tourism } \\
\text { industry. } \\
\text { 7. Deterioration of the state of engineering, } \\
\text { municipal, road and transport infrastructure } \\
\text { and cultural heritage objects. } \\
\text { 8. Unstable political situation. }\end{array}$ \\
\hline
\end{tabular}

The rural tourism is quite young direction, but rather promising for Russian Federation. In European countries, this type of recreation became very popular in the 70's of the 20 century. An obvious factor of the state importance of this type of tourism is that it can become the significant source of additional and sometimes basic income for the rural population, especially in depressed regions, to increase revenue from taxes to local budgets. For the state, the development of rural tourism is also activation of the rural community 
activities, the propagation of national cultural traditions, the preservation of the culture and historical heritage of the regions, and the development of business and cultural ties [14].

Expert assessments based on studies conducted in the Moscow, Kostroma and Ryazan regions show that the approximate level of income from agro-tourist activities per administrative region of the Russian Federation may amount to $30 \mathrm{mlns}$ rubles per year [15].

The rural territories of the Central Federal District have unique natural, climatic and cultural-historical features that allow developing practically all popular types of tourism, one of which is rural tourism, where the presence of tourism facilities is of great importance. As the Figure 4 shows, most of the objects of rural tourism are located in the Belgorod, Voronezh and Lipetsk regions. This is a consequence of the fact that regional authorities actively work in this aspect according to the means of target programs for the tourism development. However, most of the tourist sites created in the village is the local population investments.

Due to evaluation of different factors, affecting the development of rural tourism in Russian Federation, determining the strengths and weaknesses of this tourist product, and determining the "growing point", we conducted a SWOT analysis (Table 2).

The presented SWOT-analysis showed that in order to realize the potential of the tourism sector in the rural areas of the Russian Federation, following is necessary: creation of the regulatory and legislative framework for the tourism sector as a whole; expansion of tourist relationships not only between the regions of the Russian Federation, but also with foreign countries; formation of positive image of rural areas to attract not only tourists but also investors; expansion of the state support of the tourist cluster; preservation of natural and cultural-historical values within the regional targeted programs; development and modernization of road and transport infrastructure.

\section{CONCLUSION}

The development of the tourism industry will help to solve the number of socioeconomic problems of federal and regional importance. Such as: the lack of jobs in rural areas; the disappearance of small settlements, and thus a rural life; low standard of living; migration of youth to cities; lack of interest in Russian traditions; aging or absence of engineering and social infrastructure of rural settlements; the devastation of estates and villages; lack of small business in rural areas; lack of funds in local budgets; inadequate attention of investors to rural areas.

For the further development of rural tourism on the territory of Russian regions, the positioning of the tourism industry and infrastructure in the external environment by disseminating information about them and methods of branding are of particular attention. In this regard, it is important to develop passports for tourist activities, which provides the implementation of a number of activities: development of project (documentation) for tourist activities objects; development of engineering requirements and safety requirements for tourist objects; development of feasibility study of tourism projects, maintenance of accounting documents, legal support of tourist activities.

\section{REFERENCES}

1. Diagnostics of the level of sustainable development of rural areas on the basis of their monitoring: monograph / N.V. Parakhin et al // Orel: Kartush, 2016. 498 p.

2. Statement of rural areas in the Russian Federation in 2015. Annual report on the monitoring results: Scientific Publication. - Moscow: Rosinformagrotekh, 2017, 3rd. ed., $348 \mathrm{p}$.

3. Association of Tour Operators of Russia // URL: http://www.atorus.ru/news/presscentre/new/37897.html

4. Ministry of Agriculture and Food of the Republic of Tatarstan // URL: http://agro.tatarstan.ru/rus/analytic/smi/agro.htm?page=10. 
5. Decree of the Government of the Russian Federation No. 151-r dated 02.02.2015 "On the Approval of the Strategy for Sustainable Development of Rural Territories of the Russian Federation for the Period until 2030".

6. Edict of the Government of the Russian Federation of 30 November, 2010 № 2136-r "On the approval of the Concept of sustainable development of rural areas of the Russian Federation for the period until 2020".

7. Resolution of the Government of the Russian Federation of 2 August, 2011 No. 644 "On the federal target program" Development of domestic and incoming tourism in the Russian Federation (2011-2018)".

8. Decree of the Government of the Russian Federation of 15 April, 2014 No. 317 On approval of the state program of the Russian Federation "Development of Culture and Tourism" for 2013-2020 (as amended on 5 September, 2017 No. 1070).

9. Resolution of the Government of the Russian Federation of 15 July, 2013 No. 598 "On the Federal Target Program for Sustainable Development of Rural Territories for 2014 2017 and for the period until 2020".

10. Federal Law of 24.11.1996 No. 132-FZ "On the Basics of Tourism in the Russian Federation".

11. Panarina V.I. Orel region in the ratings of the Russian Federation // Bulletin of rural development and social policy. 2015. № 4 (8). P. 6-8.

12. Polukhina M.G. Economic analysis of the supporting of rural areas with objects of mass culture and tourism // Bulletin of the OSIET. 2016. № 4 (38). pp. 103-111.

13. National tourist rating: Center for Information Communications "Rating". URL: http://russia-rating.ru/info/9857.html

14. Rural tourism - a new chance for the revival and development of the village: Textbook. I E.Y. Lebedko // Bryansk: BSAA, 2011. 256 p.

15. Zdorov A.B. Agro-tourism complex: forecasting of regional development: monograph. Moscow: Tourist. 2007. 